UDC 004.9, 91, 94:378.1

Baturin O., Ivanov V., Lyfar V., Mytrokhin S., Lyhina L.

\title{
FUNCTIONAL MODEL OF DEFINITION OF INTEGRAL INDICATORS OF QUALITY OF EDUCATIONAL ACTIVITY AND QUALITY OF HIGHER EDUCATION BY INSTITUTIONS OF HIGHER EDUCATION
}

\begin{abstract}
The purpose of this work is to create methods, models and information technology tools that provide a decision support process. Meeting the challenges in determining the current level of quality of educational activity and the quality of higher education is possible only in the case of development of methods of comparative analysis of indicators of quality and success of higher education applicants, the compliance of project groups and groups with scientific and teaching staff to the relevant professional qualifications in relation to the specialty they teach, ensuring the quality filling of packages of teaching and methodical provision of disciplines, and the proper level of implementation of normative requirements in the field of higher education. In order to provide information support to the process of representing educational services at the university, a structural and informational model of processes for ensuring the quality of educational activities and the quality of higher education, and a diagram of a functional model for defining integral indicators of quality of education with a unit for evaluating the current quality status are presented. The research tasks are formulated to solve the problems of assessing the components of the system of providing higher education institutions with the quality of educational activity and the quality of higher education (internal quality assurance system). Approaches and models of qualitative and quantitative determination of system indicators are considered. Existing information technologies do not provide the introduction of methods to support the decisions on the quality of education, the author proposed information technology, which requires a comprehensive modeling of the management of educational process at all levels and structural units through the sequential formalization, comparative analysis, and development of clear corrective actions to eliminate inconsistencies aimed at bringing the current state the quality of education in accordance with the requirements of the legal and regulatory framework. In this case, the synthesis of models is carried out by combining formal methods of mathematical logic and mathematical models of development of educational activities that occur in time in a certain sequence.
\end{abstract}

Keywords: quality of educational activity, higher education quality, information technologies, software engineering, computer engineering, computer science, databases, process models, information flows.

1. Introduction. The showings of quality educational activity and quality of higher education are indicated by different quantitative parameters (such as the implementation of: Licensing conditions for conducting educational activities; Criteria for the provision and confirmation of the status of a national institution of higher education; State requirements for accreditation of training, specialty and higher education institution [1-3] and others). Between the set of parameters that determine the quality of higher education, there are multilevel relationships that determine the order and hierarchy of informational exchange, as well as the model structure of educational process which is the basis of quality education.

This model ensures compliance with Article 16 System of higher education quality assurance Law of Ukraine "On Higher Education", which essentially creates a system of providing higher education institutions with the quality of educational activity and the quality of higher education (the system of internal quality assurance).

Such a model can be represented by different structural levels: the user's structure, software and hardware structure and information flows structure combined in information technology.

The development of models, methods and information technology software is an actual scientific and technical problem, which is implemented at the professional level of specialties such as "Informational technologies", "Software engineering", "Computer engineering", "Computer science".

Solving such a task and developing software solutions for the decision support system, which are capable to implement these technologies, represents the opportunity not only to improve the learning process, but also to enable the participants of the learning process to streamline the information exchange, to bring it to the required level of quality and conduct monitoring quality of educational activities in all specialties and quality of higher education of university. Using the source data and having the prescribed criteria of compliance with the legal and regulatory framework of the Ministry of Education and Science of Ukraine, it is possible to conduct a rating among universities or (national universities) of Ukraine. This development is the most relevant for Ukrainian universities in connection with specifics of the Ukrainian legislation in the field of educational activity.

2. Data analysis and approaches for data presenting and processing in decision support systems when delivering educational services in the field of higher education.

The paper [4] conducted a detailed analysis of existing methods and approaches for the presentation and processing of data in decision support systems for the provision of educational services in higher education.

In order to ensure the informational support for delivery of educational services in the university, the following tasks shall be implemented: 
1. Performance of a comprehensive analysis of the current state of information technologies, program tools, decision support methods when delivering educational services in the field of higher education;

2. Research and performance of an analysis of the legal framework and legislation of Ukraine in the field associated with ensuring the quality of educational activities and higher education;

3. Development of educational process management models, methods and structural models of information streams which occur during functioning of such models;

4. Development of models and methods of information processing at all levels of the hierarchical structure of users and ensuring their synchronization with information streams;

5. Formalization of the information exchange processes and development of an information model of the decision support system when managing the process of delivering educational services;

6. Development of technical requirements for creation of program tools needed for implementation of the decision support system tasks;

7. Development of program tools for the DSS. Holding verification and validation of the program package, defining the area of application and determining of the developed program tools;

8. Improvement of the learning process management methods and decision-making methods in regard to the quality of the educational activities and higher education, and the factors which affect them;

9. Integration of the developed information technology into the university's educational process.

Informational support of decision-making processes aimed at achievement of the required quality level of the educational activities and higher education in the university, is the object of the research.

This development shall be made in order to create methods, models and program tools of the information technology which ensures the performance of the decision support process. Implementation of tasks of determination of the current quality level of education activities and higher education is only possible through development of methods for the benchmarking analysis of the quality and success levels of university students, qualification levels of academic stuff, provision of high-quality scope of methodological frameworks of disciplines and meeting the standard requirements in the field of higher education.

Models, methods and an information technology of creation and functioning of the decision support system in the field of assurance of required quality level of the educational activities and higher education in the university are the subject of the research.

\section{Implementation of the automated information system model proposals and on development of a DSS.}

Implementation of the automated information system (AIS) model stipulates a development of a model of structural distribution of informational and algorithmic provision among sub-systems when creating a general data bank. The general data bank includes: information on AIS subjects - the data bank on teachers, master students and candidates; descriptions of characteristics of academic and research achievements of master students - the data bank on the academic and research rating; reference information - the fixup data bank and the names data bank; the data bank on the university's structure; the data bank on curricula that contains the description of disciplines of the major curricula; the data bank on distribution of academic load; the data bank on schedules of lessons and exams; the data bank on test-and-examination sheets and record-books; the data bank on the state examination committee. Tools of monitoring and the learning process management are developed using an automated system of informational data recording and based on application of the program tools - Invision Power Board, a system for running database MySQL, PHP language, web-server Apache.

In the researched AIS [5-12], when developing the model there were used special features of that higher education institution for which they were specifically developed, while the dynamic changes which currently take place in the educational sphere including the assignment of autonomy to higher education institutions, make each AIS unique. Thus, it is quite impossible to implement the unified AIS for the whole educational sphere, excluding basic separate modules which guarantee meeting the requirements of regulatory and legal framework of the Ministry of Education and Science of Ukraine in respect to the quality of educational activities and higher education specified through different quantitative parameters (such as performance of: License terms of educational activities; Criteria for provision and confirmation of the status of a national higher education institution; State requirements to accreditation of a training program, a major and a higher education institution [1-3]).

The main functions and characteristics of many AISs of management of higher education institutions include keeping education plans, curricula, schedules of the learning process and connection with educational load, staffs and schedules of lessons, and other modules, calculation of the budget and statistics, however there was not paid due attention to monitoring of preparation of experts, assessment of rating of academic staff and students, internal and external monitoring of the higher education quality in the university. Lack of regular monitoring of the quality of educational activities and higher education which would ensure ongoing control over the learning process participants and implementation of the administrative decisions made in order to provide and achieve the required level of the education quality, would significantly improve the quality of qualifications of academic students.

The paper [4] proposed a structural-information model of the processes of ensuring the quality of educational activity and the quality of higher education at the university

As a result, a functional model for determining the integral indicators of the quality of education is proposed (Fig. 1) 


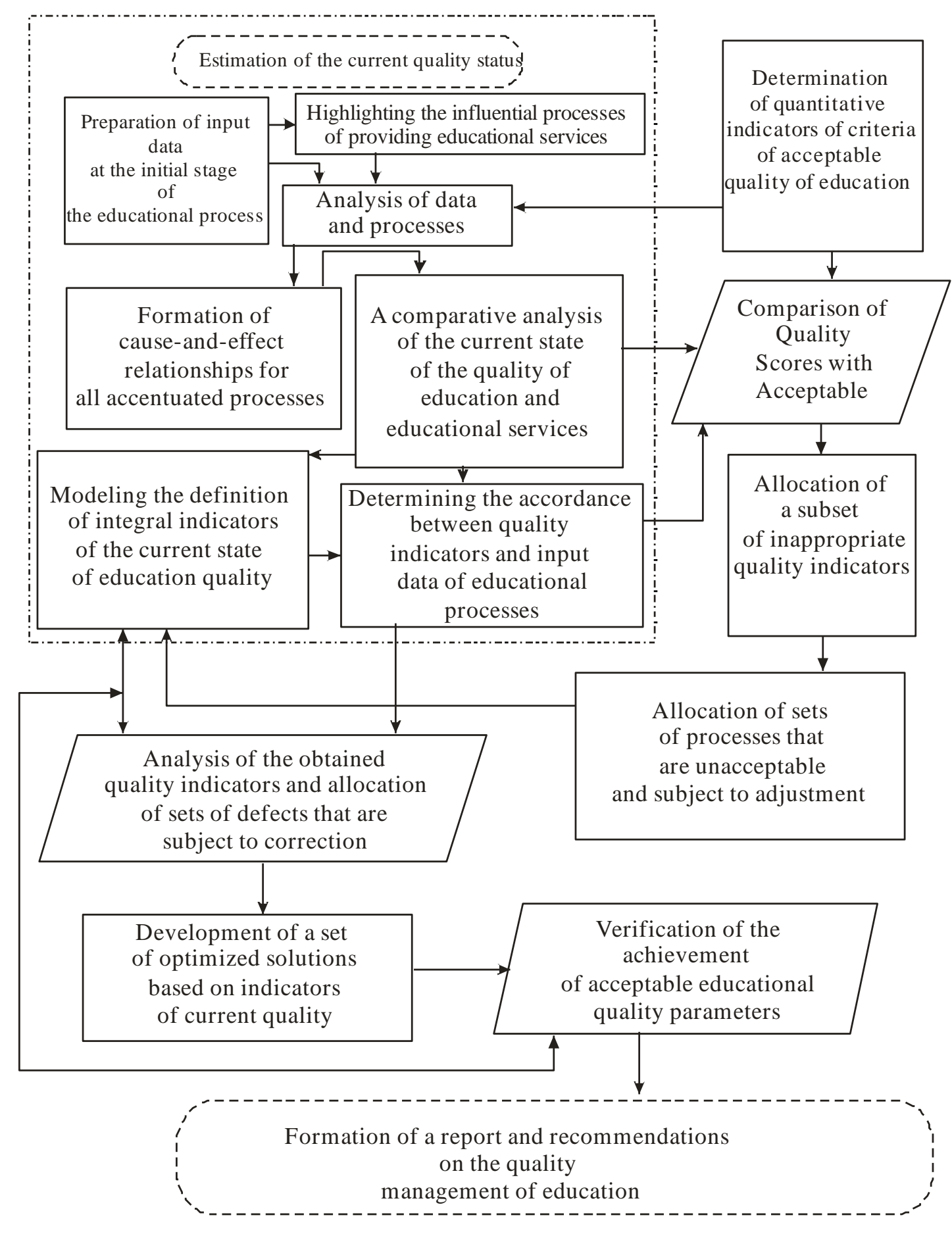

Fig. 1. Scheme of a functional model for determining the integral indicators of the quality of education

Unlike the existing information technologies, models and methods for support of decisions on the education quality, the information technology offered by the author stipulates a comprehensive modeling of actions on the educational process management through step-by-step formalization, benchmarking analysis and development of corrective actions aimed at bringing the current state of the education quality into conformity with the requirements of regulatory legal framework. At that, a synthesis of models shall be made through combining the formal methods of mathematic logics and the mathematic models of educational activity development which take place in time in the certain sequence.

\section{Conclusions.}

The methods and models proposed in the paper can form the basis for development of program tools for the information technology of the decision support system in provision of the required level of the education quality.

The methods and models offered by the authors in regard to formation of output data processing information streams, processes of decision-making and monitoring of the current state of the education services delivery were conceptually approved and formalized up to the level confirmed for algorithmization in accurate logics systems. Such 
approach allows developing technical requirements and program tools implementing the functions of the DSS information technology to the possible extent for their use by all participants of the learning process.

Integration of such DSS into the university's workflow allows not only sufficiently increasing the functional of "paper-free" technologies of information exchange and improving the quality of education services, but also bringing (based on the benchmarking analysis) the indicators of the education quality into conformity with required level of standards.

Creation of program tools with a multi-level structure of databases of users and tools for input-output allows not only systemizing dynamic indicators of the learning process, but also increasing the reliability of its preservation and functionality.

Development of a package of DSS applications in the conception specified by the authors provides flexibility of certain components and possibilities of the system development and changeability of certain blocks and tools for data reflection.

\section{References}

1. Cabinet of Ministers of Ukraine / Resolution "On Approval of Licensing Conditions for Conducting Educational Activities" / Official Bulletin of Ukraine dated 02.02.2016, No. 7, Article 345, code of the act 80480/2016 p. 23,(2016)

2. Cabinet of Ministers of Ukraine / Resolution "Procedure for granting a higher education institution a status of national, confirmation or deprivation of this status" / Official Bulletin of Ukraine dated January 19, 2017 - No. 99 , article 3031, act code $88234 / 2017$ p. 34 (2017)

3. The Ministry of Education and Science, Youth and Sports of Ukraine / Order "On approval of the state requirements for accreditation of training direction, specialty and higher education institution" / Official Gazette Ukraine from 20.07.2012, Number 52, article 2100, code of the act 62446/2012 p. 126 (2012)

4. Baturin A.: Structural-information model of processes of providing the quality of educational activity and the quality of higher education in the university. - Notes of the VI Taurida National University Vernadsky Series: Technical Sciences. Volume 30 (69) No. 2 Part 1, 2019.- p.87-93.

5. Kosiuk N.: Integrated Information System "Electronic University". Analysis of the state of university management information systems in project rartner countries. -Sumy: Sumy State University, pp. 62-90 (2016)

6. Kosiuk M.: University Management: Information Support and Computerization - Experience of Khmelnytsky National University. Actual problems of specialists in ICT / Conference Processings. - Sumy: Sumu State University pp. $48-55,(2013)$

7. Methodological bases of creation, introduction and development of the integrated information management system of the university. Sumy: Sumy State University, p. 343 (2015)

8. Mokin, B.: Development and implementation of document management and process management training master training. Optoelectronic Information-Power Technologies. No. 2. - pp. 5-12, (2006)

9. Voronkin, O.: Development of information and communication technologies for students of higher educational institutions of Ukraine in the 90-ies of XX century. pp. 99-116, (2014) http: //nbuv.gov.ua/j-pdf/itvo_2014_20_12.pdf.

10. Gurevich, R.: Information and communication technologies in vocational education. Corresponding Member National Academy of Sciences of Ukraine. - Lviv, p. 506(2012)

11. Kryukov V.: Corporate Information Distribution: Methodology, Models, Solutions. Vladivostok: Dalnauka, p. 308 (2007)

12. Information management system of MGTU N. E. Bauman "Electronic University": concept and implementation. - M.: Publishing-house of MGTU N. E. Bauman. - p. 376 (2009)

Метою даної розробки є створення методів, моделей $і$ програмних засобів інформаційної технологї, яка забезпечує проиес підтримки прийняття рішень. Розв'язання задач з визначення поточного рівня якості освітньої діяльності та якості вищої освіти можливе, у разі розробки методів порівняльного аналізу показників якості та успішності здобувачів вищої освіти, відповідності проектних груп і груп забезпечення науковопедагогічними працівниками відповідної фахової кваліфікації щзодо спеціальності, яку обслуговують, забезпечення якісного наповнення пакетів навчально-методичного забезпечення дисциплін, та належного рівня виконання нормативних вимог у сфері вищої освіти. Для забезпечення інформаційної підтримки процесу представлення освітніх послуг в університеті наведена структурно-інформаційна модель процесів забезпечення якості освітньої діяльності та якості вищої освіти та схема функціональної моделі визначення інтегральних показників якості освіти з блоком оцінювання поточного стану якості. Сформульовані завдання досліджень для вирішення проблем оцінки складових в системі забезпечення закладами вищої освіти якості освітньої діяльності та якості вищої освіти (системи внутрішнього забезпечення якості). Розглянуті підходи та моделі якісного та кількісного визначення показників системи. Існуючі інформаційні технології не забезпечують запровадження методів підтримки рімень щздо якості освіти, запропонована автором інформаційна технологія передбачає комплексне моделювання дій управління освітнім процесом на всіх рівнях в структурних підрозділах шляхом послідовної формалізації, порівняльного аналізу та розробки чітких коригуючих дій шчодо усунення невідповідностей, спрямованих на приведення поточного стану якості освіти до відповідності вимогам нормативно-правої бази. При изьому синтез моделей здійснюється иляхом поєднання формальних 
методів математичної логіки і математичних моделей розвитку освітньої діяльності, щзо відбуваються в часі в певній послідовності.

Ключові слова: якість освітньої діяльності, якість вищої освіти, інформачійні технологї, інженерія програмного забезпечення, комп'ютерна інженерія, комп'ютерні науки, бази даних, моделі прочесів, інформаційні потоки.

Baturin O. - Senior Lecturer of Department of Programming and Mathematics, Volodymyr Dahl East Ukrainian National University aibaturin1973@gmail.com

Ivanov V. - Ph. D. in Project automation systems, Associate professor of Department of Programming and Mathematics, Volodymyr Dahl East Ukrainian National University

vetgen75@gmail.com

Lyfar V. - Doctor in Engineering, Ph. D. in Technical Sciences, Professor of Department of Programming and Mathematics, Volodymyr Dahl East Ukrainian National University

lyfarva61@ukr.net

Mytrokhin S. - PhD, Associate Professor of Department of Programming and Mathematics, Vladimir Dahl East Ukrainian National University

mytrokhin@snu.edu.ua

Lyhina L. - Senior Lecturer of Department of Programming and Mathematics, Vladimir Dahl East Ukrainian National University

kaf_mif@ukr.net 